\title{
Puddling, Direct Seeding, Mechanical Transplanting for Rice: Effect on Soil Characteristics and Productivity of Rice
}

\section{Evans Asenso}

University of Ghana

\section{Zhimin Wang}

South China Agricultural University

Jiuhao Li

South China Agricultural University

Lian Hu ( $\square$ lianhu@scau.edu.cn )

South China Agricultural University

\section{Research Article}

Keywords: Tillage , Establishment approach , Rice , SOC , Grain yield , Paddy field

Posted Date: September 1st, 2021

DOl: https://doi.org/10.21203/rs.3.rs-811574/v1

License: (c) (i) This work is licensed under a Creative Commons Attribution 4.0 International License. Read Full License 


\title{
Puddling, direct seeding, mechanical transplanting for rice: Effect on soil characteristics and productivity of rice
}

\author{
Evans Asenso ${ }^{1,3}$, Zhimin Wang ${ }^{2}$, Jiuhao $\mathrm{Li}^{1^{*}}{ }^{\text {, Lian } \mathrm{Hu}^{2 *}}$ \\ 1 College of Water Conservancy and Civil Engineering, South China Agricultural University, \\ Guangdong 510642, China \\ 2 College of Engineering, South China Agricultural University, Guangdong 510642, China \\ 3 Department of Agricultural Engineering, School of Engineering Sciences, University of Ghana; \\ *Correspondence: jhli@scau.edu.cn (J. Li); lianhu@scau.edu.cn (L. Hu)
}

\begin{abstract}
Why puddling? It is an important operation to minimize soil nutrient leaching and thereby increasing the availability of plant nutrients and achieving reduced soil condition. Good puddle field conditions are needed to create favorable environment for normal growth of rice plants. However, long-term effects of puddling could lead to forms of large clods in fine textured soils; resulting in negative effect on the soil characteristics, preventing seed-soil contacts and leading to decline in rice yield. This study was conducted in 2 years with treatment including; puddling the land twice with moldboard plow and pre-germinated seeds were hill-seeded with direct seeding machine (PD), puddling the land twice with rotary tiller and pre-germinated seeds were hill-seeded with direct seeding machine (RD), puddling the land twice with moldboard plow and 15-day-old seedlings were hill-transplanted with transplant machine (PT), and puddling the land twice with rotary tiller and 15-day-old seedlings were hill-transplanted with transplant machine (RT) to assess the effect of puddling, direct seeding, and mechanical transplanting on soil characteristics and rice yield. Results revealed significant improvement in the bulk density and increase in SOC, N, P and $\mathrm{K}$ in PD. The maximum microbial population was found in PD. Rice yield showed a higher productivity increase of $7.44 \mathrm{t} \cdot \mathrm{ha}^{-2}$ and $3.91 \mathrm{t} \cdot \mathrm{ha}^{-2}$ in 2017, and $7.85 \mathrm{t} \cdot \mathrm{ha}^{-2}$ and $3.94 \mathrm{t} \cdot \mathrm{ha}^{-2}$ in 2018 respectively for $1 \mathrm{H}$ and $2 \mathrm{H}(1 \mathrm{H}$ : 1 st harvest, and $2 \mathrm{H}$ : $2 \mathrm{nd}$ harvest) in PD. Overall, $\mathrm{PD}$ was found to be the most suitable puddling and rice establishment approach under paddy fields for soil improvement and increasing rice yield.
\end{abstract}

Keywords Tillage $\cdot$ Establishment approach $\cdot$ Rice $\cdot$ SOC $\cdot$ Grain yield $\cdot$ Paddy field

\section{Introduction}

Rice (Oryza sativa L.) is cultivated in about 120 countries globally, about 214 and 173 million tons are produced in China and India respectively together accounting for more than 50\% of the global production. $90 \%$ of the top 10 and $65 \%$ of the top 20 countries producing rice in the world are from Southeast Asia ${ }^{1}$. Consequently, enhancing and sustaining the cultivation of rice is indispensable for the global food security. Cultivation of rice in China is primarily thru by mechanical transplanting and direct seeding in paddy fields. The impact of puddling on rice output varies according to soil indicators and environmental conditions ${ }^{2}$. Puddling is done normally to create suitable soil environment for seed development, and easy transplanting of seedlings of rice 
by enhancing soil water evaporation, and breaking down and dispersing of soil aggregates into micro-aggregates and smaller particles ${ }^{3,4}$. Asia's rice production is mostly cultivated by traditionally transplanting of seedlings of 25-30-day-old into puddled soils, due to the fact that puddled-transplanted methods upsurge nutrient accessibility and impedes weed growth ${ }^{5}$. However, mechanical rice transplanting is the practice of transplanting young seedlings of rice which having been raised-up in a climatic box in a nursery using a paddy field transplanter. Rice seedlings between the optimum age of 14-18 days are transplanted onto the puddly field ${ }^{6}$. But, now, as a result of the looming water crisis and shortage of labor during transplanting, farmers in Asia are considering the option of direct seeding ${ }^{7}$. Direct seeding (DS) of rice is a technique of rice cultivation where the farmer directly sows the paddy seeds in the field, escaping transplanting process $^{8}$. DS are done to save water, saves labor, decrease cultivation cost, cause less damage to soil physical health and less greenhouse gases production. The puddling type and the mode of rice establishment on the paddy fields has a direct effect on both soil characteristics and the grain yield, as an increase in grain yield is dependent on the improvement in the soil characteristics. The aim of this study is to assess the effect of puddling and two types of rice establishment approaches (direct seeding and mechanical transplanting) on soil characteristics and their influence on rice yield. Our hypothesis was that puddling type combined with direct seeding or mechanical transplanting will improve soil characteristics. We also anticipated that rice yield will be increased by the puddling and the establishment approaches.

\section{Materials and methods}

\section{Site description}

The study was initiated in 2017/18 at the Zengcheng Experimental Station $\left(23^{\circ} 13^{\prime}\right.$ N, $113^{\circ} 81^{\prime}$ E, altitude $11 \mathrm{~m}$, Fig. 1) of the South China Agricultural University, located in Guangzhou City, Guangdong. The site has a subtropical monsoon climate, and the annual precipitation for 2017 $(2660.09 \mathrm{~mm}), 2018(2758.21 \mathrm{~mm})$; annual wind speed for $2017\left(23.4 \mathrm{~m} \cdot \mathrm{s}^{-1}\right), 2018\left(24.7 \mathrm{~m} \cdot \mathrm{s}^{-1}\right)$; annual temperature for $2017\left(21.3^{\circ} \mathrm{C}\right), 2018\left(22.8^{\circ} \mathrm{C}\right)$; annual humidity for $2017(728.3 \%), 2018$ (713.8\%), and the annual sunshine hours are 2017 (1707.2 h) and $2018(1623.5 \mathrm{~h})$. The soil of the study site is classified as Lateritic Red Earth developed from the Quaternary Red Earth ${ }^{9}$. The soil properties of the top soil layer $(0-30 \mathrm{~cm})$ of the ratoon rice field before the experiment are shown in Table 1.
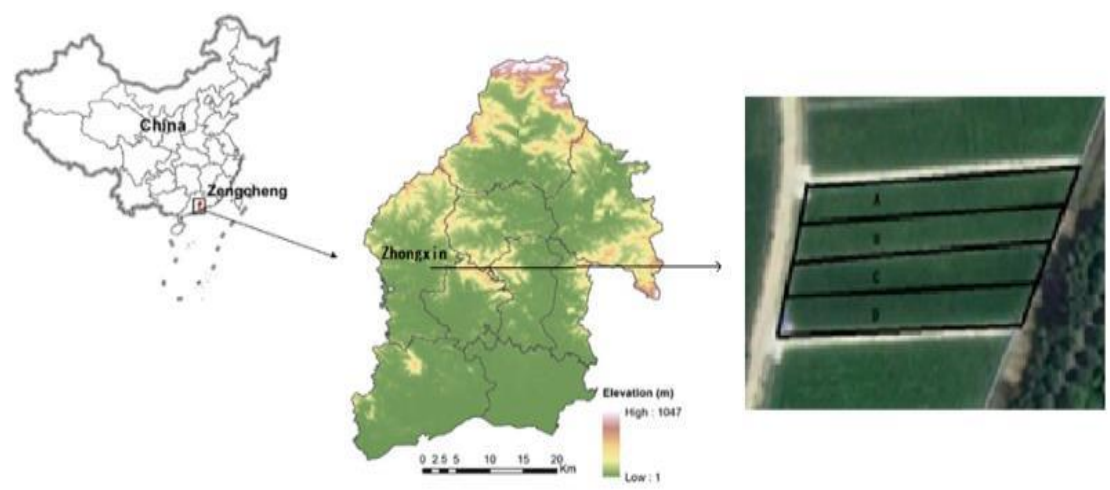

Figure 1. Site location of South China Agricultural University Research Station, Zhongxi Town, Zengcheng District, Guangzhou City, Guangdong Province 
Table 1 Basic soil properties at $0-30 \mathrm{~cm}$ soil depth before the experiment.

\begin{tabular}{|c|c|c|c|c|c|c|}
\hline \multicolumn{7}{|c|}{ Soil Physical properties } \\
\hline Climate & Sand $(\%)$ & Silt (\%) & Clay $(\%)$ & Soil Texture & \multicolumn{2}{|c|}{ Bulk density $\left(\mathrm{g} \cdot \mathrm{cm}^{-3}\right)$} \\
\hline Subtropical Monsoon & 65 & 27 & 8 & Sandy-loam & & 1.60 \\
\hline \multicolumn{7}{|c|}{ Soil Chemical properties } \\
\hline $\mathrm{SOC}\left(\mathrm{g} \cdot \mathrm{kg}^{-1}\right)$ & Av. $\mathrm{N}\left(\mathrm{mg} \cdot \mathrm{kg}^{-1}\right)$ & Av. P (mg.kg $\left.{ }^{-1}\right)$ & Av. $\mathrm{K}\left(\mathrm{mg} \cdot \mathrm{kg}^{-1}\right)$ & $\mathrm{T} \mathrm{N}\left(\mathrm{g} \cdot \mathrm{kg}^{-1}\right)$ & T P $\left(g \cdot \mathrm{kg}^{-1}\right)$ & $\mathrm{T} \mathrm{K}\left(\mathrm{g} \cdot \mathrm{kg}^{-1}\right)$ \\
\hline 10.04 & 39.52 & 13.32 & 31.19 & 0.50 & 0.26 & 15.10 \\
\hline \multicolumn{7}{|c|}{ Soil Biological properties } \\
\hline $\begin{array}{c}\text { Bacteria } \\
\left(\times 10 \mathrm{cfu} \cdot \mathrm{g}^{-1} \text { dry soil }\right)\end{array}$ & $\begin{array}{c}\text { Fungi } \\
103 \mathrm{cfu} \cdot \mathrm{g}^{-1} \text { dry soil) }\end{array}$ & $\begin{array}{l}\text { Actinomycetes }(\times 104 \\
\left.\text { cfu }^{\prime} \mathrm{g}^{-1} \text { dry soil }\right)\end{array}$ & \multicolumn{2}{|c|}{$\begin{array}{c}\text { Catalase } \\
{\left[0.1 \mathrm{NKMnO}_{4}\left(\mathrm{~mL}^{-1-1}\right)\right]}\end{array}$} & $\begin{array}{l}\text { Phosphatase } \\
{\left[\mathrm{P}_{2} \mathrm{O}_{5}\left(\mathrm{mg} \cdot \mathrm{kg}^{-1}\right)\right]}\end{array}$ & $\begin{array}{c}\text { Urease } \\
{\left[\mathrm{NH}_{4}{ }^{+}-\mathrm{N}\left(\mathrm{mg} \cdot \mathrm{kg}^{-1}\right)\right]}\end{array}$ \\
\hline 2.21 & 1.21 & 2.80 & \multicolumn{2}{|l|}{1.61} & 69.03 & 47.50 \\
\hline
\end{tabular}

\section{Experimental design and farm management}

Two puddling practices, plowing $(\mathrm{P})$ and rotary $(\mathrm{R})$ were adopted with two establishment approaches, direct seeding (D) and mechanical transplanting (T). The treatment description is as below ${ }^{10}$ :

- Moldboard plowing with direct seeding (PD): Before planting, the land was puddle twice with plow cultivator. Pregerminated seeds were hill-seeded with direct seeding machine at a space of $25 \times 15 \mathrm{~cm}$ while each hill was planted with $4-6$ seeds.

- Rotary tillage with direct seeding (RD): Before planting, the land was puddle twice with rotary cultivator. Pregerminated seeds were hill-seeded with direct seeding machine at a space of $25 \times 15 \mathrm{~cm}$ while each hill was planted with $4-6$ seeds.

- Moldboard plowing with mechanical transplanting (PT): Before transplanting, the land was puddle twice with plow cultivator. 15-day-old seedlings were hill-transplanted with transplant machine at a space of $25 \times 15 \mathrm{~cm}$ while each hill was transplanted with 4-6 seedlings.

- Rotary tillage with mechanical transplanting (RT): Before transplanting, the land was puddle twice with rotary cultivator. 15-day-old seedlings were hill-transplanted with transplant machine at a space of $25 \times 15 \mathrm{~cm}$ while each hill was transplanted with 4-6 seedlings.

A fragrant rice cultivar, Meixiangzhan-2, with maturity period between 111-114 days and widely planted in South China, sown on direct hill drop method by 2BDCSP Precision Rice Hill-Drop Drilling Machine and transplanted by YANMAR VP7D25 Rice Transplanter was used in the experiment. Before sowing, the seeds were soaked in water for $24 \mathrm{~h}$, germinated in manual climatic boxes for another $12 \mathrm{~h}$ and shade-dried. Some of the germinated seeds were sown in polyvinyl chloride trays for nursery raising.

\section{Soil sampling and analysis}

Pre-soil and after rice were harvested, bulk soil samples were collected from three locations on each of treatment plot using an auger. Soil samples collected from the same soil layers $(0-10,10-$ 20 and $20-30 \mathrm{~cm}$ ) at each treatment plot were mixed. Soil samples for physical, chemical and biological determination were obtained in each treatment plot using a cylinder (500 $\mathrm{mm}$ diameter). Soil samples collected were sealed using aluminum lunch boxes and returned to the laboratory for analysis.

\section{Soil bulk density measurement}

Soil bulk density was used as a significant indicator of changes in soil structure and water retention capacity $^{11}$ and was progressively determined from $50 \mathrm{~mm}$ diameter sampler cores to a depth of 30 
$\mathrm{cm}$. The soil was measured from undisturbed soil cores collected from four depths $(0-10,10-20$ and $20-30 \mathrm{~cm}$ ). Soil cores were weighed wet, dried in an oven at $105^{\circ} \mathrm{C}$ for $48 \mathrm{~h}$, and weighed again to determine the soil bulk density ${ }^{12}$.

\section{Soil chemical characteristics measurements (pH, SOC, available NPK and total NPK)}

Soil $\mathrm{pH}$ was determined using the combined glass electrode method ${ }^{13,14}$. SOC was determined by $0.5 \mathrm{~mol} / \mathrm{L}$ potassium sulfate extraction-high temperature external thermal potassium dichromate oxidation-volume method ${ }^{15}$. Available $\mathrm{N}$ was determined by Alkali solution diffusion method ${ }^{\mathbf{1 4}}$. Available $\mathrm{P}$ was determined by Bray No. 1 extract method ${ }^{16}$. Available $\mathrm{K}$ was determined by the Colorimetric method (Whittles and Little, 1950). Total $\mathrm{N}$ was determined by Kjeldahl distillation method $^{15}$. Total $\mathrm{P}$ was determined by Sodium hydroxide melting - molybdenum antimony colorimetric method ${ }^{15}$. Total $\mathrm{K}$ was determined by Alkali fusion - flame photometer or atomic absorption spectrophotometer method ${ }^{15}$.

Soil biological characteristics measurements (Bacteria, fungi, actinomycetes, urease, catalase and phosphatase)

Soil bacteria, fungi and actinomycetes were determined by the Plate inoculation method ${ }^{15}$. Soil urease was determined by Automated calorimetric method ${ }^{15}$. Soil catalase was determined by Volumetric method ${ }^{15}$. Soil phosphatase was determined by Phenyl phosphate sodium colorimetric method $^{15}$.

\section{Grain yield analysis}

Rice grain were harvested at maturity from three sampling areas $\left(1.00 \mathrm{~m}^{2}\right)$ randomly selected in each plot and machine-threshed. Harvested grains were sun-dried at $13.5 \%$ moisture content and weighted in order to determine the grain yield. FUQIANG 4LZ-427 Full-Fill Grain Combine Harvester was used to harvest the whole rice filed.

\section{Statistical analysis}

Statistical analysis was conducted using IBM SPSS software 23.0 (SPSS Inc., Chicago, IL, USA). Duncan's multiple range test (DMRT) at 5\% probability was performed to compare the means of different treatments.

\section{Results}

Soil bulk density as affected by puddling and rice establishment approach

Soil bulk density values in 2017 and 2018 (1H: 1st harvest, and 2H: 2nd harvest) were affected by puddling and rice crop establishment approaches (Fig. 2). Significant differences (1.65, 1.59, 1.47 and $1.54 \mathrm{~g} \cdot \mathrm{cm}^{-3}$ and $1.61,1.54,1.48$ and $1.52 \mathrm{~g} \cdot \mathrm{cm}^{-3}$ respectively for RT, PT, PD and RD in $1 \mathrm{H}$ and $2 \mathrm{H}$ ) were recorded among all the puddling and rice establishment approaches in 2017. Similarly, 1.44, 1.36, 1.29 and $1.37 \mathrm{~g} \cdot \mathrm{cm}^{-3}$ and $1.58,1.53,1.29$ and $1.45 \mathrm{~g} \cdot \mathrm{cm}^{-3}$ were respectively recorded under RT, PT, PD and RD in $1 \mathrm{H}$ and $2 \mathrm{H}$ in 2018. Comparatively, PD recorded lower bulk density in $2017(8.84 \%$ and $8.11 \%$ respectively for $1 \mathrm{H}$ and $2 \mathrm{H})$ than in $2018(24.03 \%$ respectively for $1 \mathrm{H}$ and $2 \mathrm{H}$ ) compared to the initial value in Table 1 . 


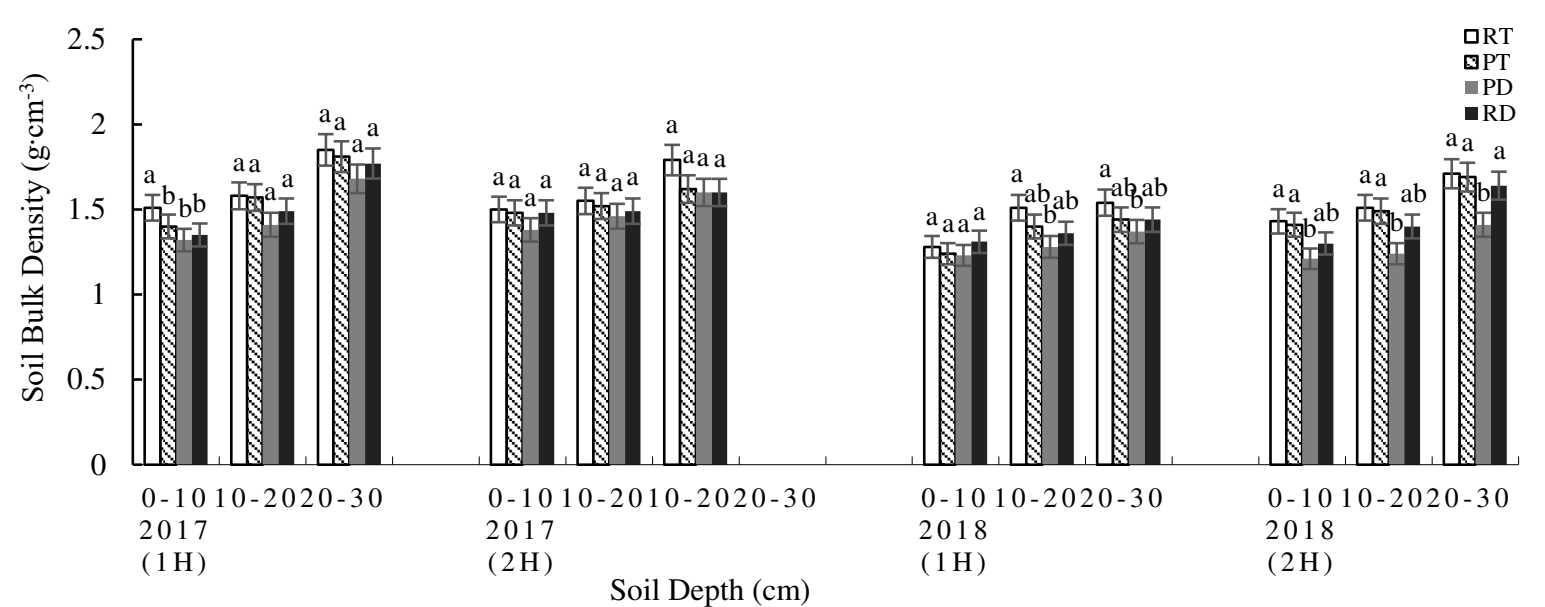

Figure 2. Puddling, direct seeding and mechanical transplanting on soil bulk density. PD: moldboard plowing with direct seeding, RD: rotary tiller with direct seeding, PT: moldboard plowing with mechanical transplanting, RT: rotary tiller with mechanical transplanting. Different letters within a column represent significant differences at the 5\% level of DMRT. (1H: 1st harvest, and 2H: 2nd harvest).

\section{Soil pH and SOC as affected by puddling and rice establishment approach}

Soil $\mathrm{pH}$ varied considerably among puddling and rice crop establishment approaches. The results showed that $\mathrm{pH}$ was in the range of 5.74 to 6.41 and 5.23 to 7.73 respectively for 2017 and 2018, however, the highest $\mathrm{pH}$ of 6.14 and 6.27 (for $1 \mathrm{H}$ and $2 \mathrm{H}$ in 2017) and 6.11 and 7.60 (for $1 \mathrm{H}$ and $2 \mathrm{H}$ respectively in 208) was recorded under PD (Fig. 3a). SOC was significantly different in 2017 compared to in 2018; however, the highest value 11.47 and $13.12 \mathrm{~g} \cdot \mathrm{kg}^{-1}$ (for $1 \mathrm{H}$ and $2 \mathrm{H}$ in 2017), and 11.79 and $12.31 \mathrm{~g} \cdot \mathrm{kg}^{-1}$ (for $1 \mathrm{H}$ and $2 \mathrm{H}$ in 2018) statistically with highest increase of 14.24 and $30.68 \%$ (for $1 \mathrm{H}$ and $2 \mathrm{H}$ in 2017) and 17.43 and $12.31 \%$ (respectively for $1 \mathrm{H}$ and $2 \mathrm{H}$ in 2018) in $0-30 \mathrm{~cm}$ soil depth were recorded under PD (Fig. 3b).

\section{Available NPK as affected by puddling and rice establishment approach}

PD resulted in highest activity of available $\mathrm{N}\left(47.45\right.$ and $\left.58.41 \mathrm{mg} \cdot \mathrm{kg}^{-1}\right)$ which markedly increased by 20.29 and $47.80 \%$ in 2017 (for $1 \mathrm{H}$ and $2 \mathrm{H}$ respectively), and 43.31 and $56.53 \mathrm{mg} \cdot \mathrm{kg}^{-1}$ ) resulting to an increase of 9.59 and $43.04 \%$ in 2018 for $1 \mathrm{H}$ and $2 \mathrm{H}$ respectively (Table 2). Available $\mathrm{P}$ content was significantly varied among puddling and rice crop establishment approach. The highest 13.42 and $13.86 \mathrm{mg} \cdot \mathrm{kg}^{-1}$ resulting in an increase of 0.75 and $4.05 \%$ in 2017 (for $1 \mathrm{H}$ and $2 \mathrm{H}$ respectively), and 13.61 and $13.98 \mathrm{mg} \cdot \mathrm{kg}^{-1}$ resulting in an increase of 2.18 and $4.95 \%$ in 2018 (for $1 \mathrm{H}$ and $2 \mathrm{H}$ respectively) of available $\mathrm{P}$ were observed under PD (Table 2). The highest available $\mathrm{K}$ (43.32 and $49.82 \mathrm{mg} \cdot \mathrm{kg}^{-1}$ ) resulting in an increase of 38.89 and $59.73 \%$ in 2017 (for $1 \mathrm{H}$ and $2 \mathrm{H}$ ), and 38.85 and $53.55 \mathrm{mg} \cdot \mathrm{kg}^{-1}$ resulting in an increase of 24.56 and $71.69 \%$ in 2018 (for $1 \mathrm{H}$ and $2 \mathrm{H}$ respectively) were recorded under PD (Table 2). 


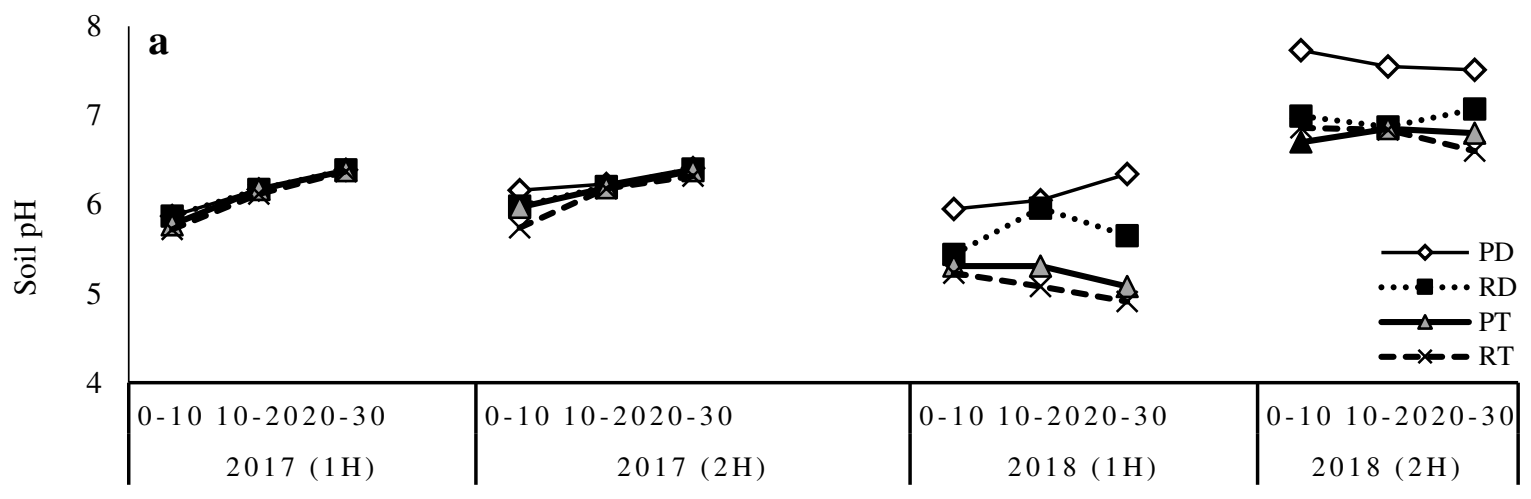

Soil Depth $(\mathrm{cm})$

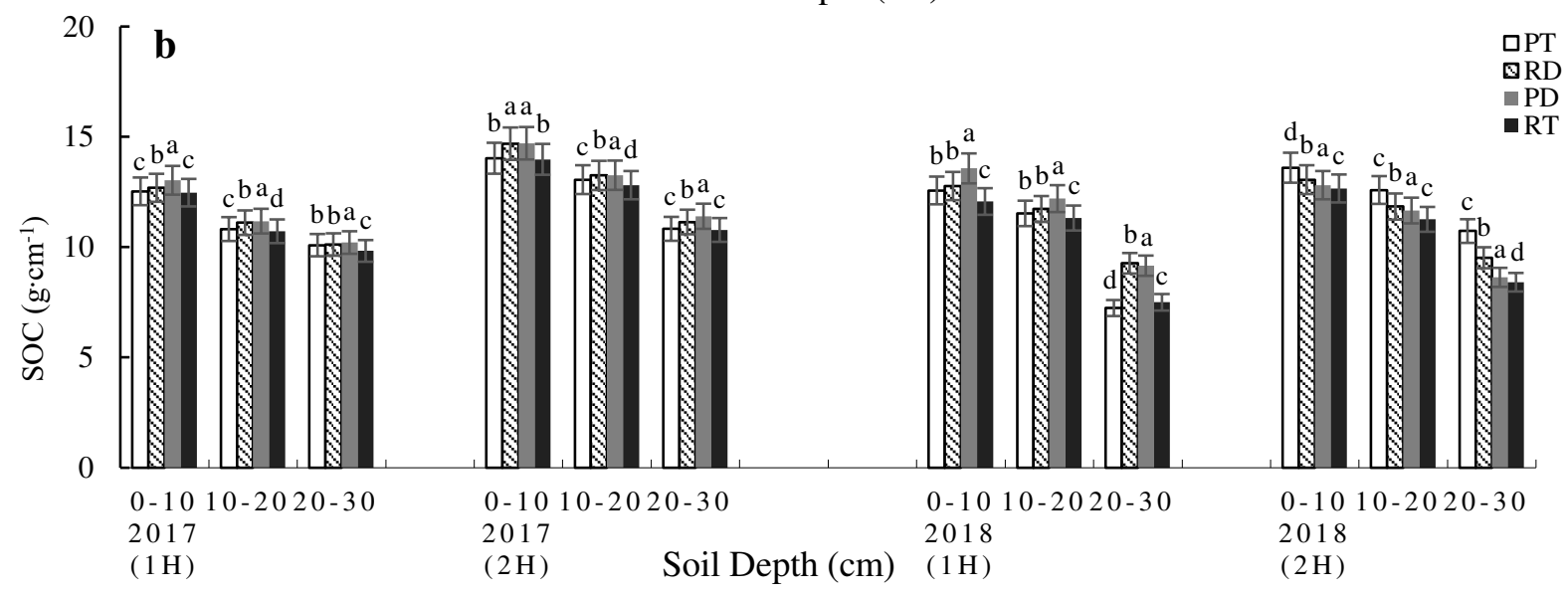

Figure 3. Puddling, direct seeding and mechanical transplanting on soil (a) soil pH and (b) soil organic carbon. PD: moldboard plowing with direct seeding, RD: rotary tiller with direct seeding, PT: moldboard plowing with mechanical transplanting, RT: rotary tiller with mechanical transplanting. Different letters within a column represent significant differences at the $5 \%$ level of DMRT. (1H: 1st harvest, and 2H: 2nd harvest).

Table 2 Available NPK condition as affected by puddling and rice establishment approach.

\begin{tabular}{|c|c|c|c|c|c|c|c|}
\hline \multirow[t]{2}{*}{$\begin{array}{c}\text { Soil } \\
\text { Depth }\end{array}$} & \multirow[t]{2}{*}{ Treatment } & \multicolumn{2}{|c|}{$\begin{array}{l}\text { Available Nitrogen } \\
\left(\mathrm{mg} \cdot \mathrm{kg}^{-1}\right)\end{array}$} & \multicolumn{2}{|c|}{$\begin{array}{l}\text { Available Phosphorus } \\
\left(\mathrm{mg} \cdot \mathrm{kg}^{-1}\right)\end{array}$} & \multicolumn{2}{|c|}{$\begin{array}{c}\text { Available Potassium } \\
\left(\mathrm{mg} \cdot \mathrm{kg}^{-1}\right)\end{array}$} \\
\hline & & $2017(1 \mathrm{H})$ & $2017(2 \mathrm{H})$ & $2017(1 \mathrm{H})$ & $2017(2 \mathrm{H})$ & $2017(1 \mathrm{H})$ & $2017(2 \mathrm{H})$ \\
\hline \multirow{4}{*}{$0-10 \mathrm{~cm}$} & PD & $56.32 \mathrm{a}$ & $64.87 \mathrm{a}$ & $14.70 \mathrm{a}$ & $15.76 \mathrm{a}$ & $48.68 \mathrm{a}$ & $54.39 \mathrm{a}$ \\
\hline & $\mathrm{RD}$ & $54.91 \mathrm{~b}$ & $61.09 \mathrm{~b}$ & $14.51 \mathrm{~b}$ & $15.67 \mathrm{ab}$ & $46.14 b$ & $52.00 \mathrm{~b}$ \\
\hline & $\mathrm{PT}$ & $53.234 \mathrm{c}$ & $60.06 c$ & $14.42 \mathrm{~b}$ & $15.59 \mathrm{bc}$ & $43.58 \mathrm{c}$ & $49.47 \mathrm{c}$ \\
\hline & $\mathrm{RT}$ & $52.49 \mathrm{c}$ & $58.67 \mathrm{~d}$ & $14.37 \mathrm{~b}$ & $15.47 \mathrm{c}$ & $43.00 \mathrm{c}$ & $47.88 \mathrm{~d}$ \\
\hline \multirow{4}{*}{$10-20 \mathrm{~cm}$} & PD & $47.42 \mathrm{a}$ & $60.40 \mathrm{a}$ & $14.23 \mathrm{a}$ & $14.33 \mathrm{a}$ & $43.66 \mathrm{a}$ & $49.94 \mathrm{a}$ \\
\hline & RD & $44.15 b$ & $54.41 \mathrm{~b}$ & $13.98 \mathrm{~b}$ & $14.18 \mathrm{ab}$ & $42.51 \mathrm{a}$ & $45.71 b$ \\
\hline & PT & $42.04 \mathrm{c}$ & $52.36 \mathrm{c}$ & $13.71 \mathrm{c}$ & $13.94 b c$ & $41.01 \mathrm{~b}$ & $42.41 \mathrm{c}$ \\
\hline & $\mathrm{RT}$ & $41.47 \mathrm{c}$ & $51.78 \mathrm{c}$ & $13.66 \mathrm{c}$ & $13.87 \mathrm{c}$ & $39.92 b$ & $40.86 \mathrm{~d}$ \\
\hline \multirow{6}{*}{$20-30 \mathrm{~cm}$} & PD & $38.88 \mathrm{a}$ & $49.96 a$ & $11.33 \mathrm{a}$ & $11.51 \mathrm{a}$ & $37.63 a$ & $45.12 \mathrm{a}$ \\
\hline & $\mathrm{RD}$ & $38.49 \mathrm{a}$ & $47.30 \mathrm{~b}$ & $11.21 \mathrm{a}$ & $11.32 \mathrm{ab}$ & $34.99 \mathrm{~b}$ & $40.52 b$ \\
\hline & $\mathrm{PT}$ & $37.54 \mathrm{~b}$ & $43.58 \mathrm{c}$ & $10.92 b$ & $11.26 \mathrm{~b}$ & $32.03 \mathrm{c}$ & $38.83 \mathrm{c}$ \\
\hline & RT & $36.36 \mathrm{c}$ & $42.79 \mathrm{c}$ & $10.88 \mathrm{~b}$ & $11.20 \mathrm{~b}$ & $31.17 \mathrm{~d}$ & $36.84 \mathrm{~d}$ \\
\hline & & \multicolumn{2}{|c|}{$\begin{array}{c}\text { Available Nitrogen } \\
\left(\mathrm{mg} \cdot \mathrm{kg}^{-1}\right)\end{array}$} & \multicolumn{2}{|c|}{$\begin{array}{c}\text { Available Phosphorus } \\
\left(\mathrm{mg} \cdot \mathrm{kg}^{-1}\right)\end{array}$} & \multicolumn{2}{|c|}{$\begin{array}{c}\text { Available Potassium } \\
\left(\mathrm{mg} \cdot \mathrm{kg}^{-1}\right)\end{array}$} \\
\hline & & $2018(1 \mathrm{H})$ & $2018(2 \mathrm{H})$ & $2018(1 \mathrm{H})$ & $2018(2 \mathrm{H})$ & $2018(1 \mathrm{H})$ & $2018(2 \mathrm{H})$ \\
\hline \multirow[b]{2}{*}{$0-10 \mathrm{~cm}$} & PD & $52.43 \mathrm{a}$ & $73.79 \mathrm{a}$ & $13.98 \mathrm{a}$ & $15.80 \mathrm{a}$ & $41.69 \mathrm{a}$ & $56.53 \mathrm{a}$ \\
\hline & $\mathrm{RD}$ & $49.19 b$ & $71.63 b$ & $13.53 \mathrm{~b}$ & $15.00 \mathrm{~b}$ & $39.80 \mathrm{~b}$ & $52.67 \mathrm{~b}$ \\
\hline
\end{tabular}




\begin{tabular}{|c|c|c|c|c|c|c|c|}
\hline & PT & $47.58 \mathrm{c}$ & $65.80 \mathrm{c}$ & $13.12 \mathrm{c}$ & $14.00 \mathrm{c}$ & $36.19 \mathrm{c}$ & $49.00 \mathrm{c}$ \\
\hline & RT & $47.25 \mathrm{c}$ & $64.29 \mathrm{c}$ & $12.53 \mathrm{~d}$ & $13.04 \mathrm{~d}$ & $33.93 d$ & $48.80 \mathrm{c}$ \\
\hline \multirow{4}{*}{$10-20 \mathrm{~cm}$} & PD & $45.33 a$ & $51.13 \mathrm{a}$ & $13.73 \mathrm{a}$ & $13.60 \mathrm{a}$ & $40.89 \mathrm{a}$ & $53.76 \mathrm{a}$ \\
\hline & RD & $44.66 \mathrm{a}$ & $44.23 b$ & $11.53 \mathrm{~b}$ & $13.13 b$ & $35.97 \mathrm{~b}$ & $51.18 \mathrm{~b}$ \\
\hline & PT & $41.46 \mathrm{~b}$ & $44.01 \mathrm{~b}$ & $11.20 \mathrm{~b}$ & $11.60 \mathrm{c}$ & $34.44 \mathrm{c}$ & $45.96 c$ \\
\hline & RT & $37.54 \mathrm{c}$ & $37.54 \mathrm{c}$ & $11.18 \mathrm{~b}$ & $8.13 \mathrm{~d}$ & $30.04 \mathrm{~d}$ & $42.80 \mathrm{~d}$ \\
\hline \multirow{4}{*}{$20-30 \mathrm{~cm}$} & PD & $32.16 \mathrm{a}$ & $44.66 a$ & $13.11 \mathrm{a}$ & $13.27 \mathrm{a}$ & $33.98 \mathrm{a}$ & $50.35 \mathrm{a}$ \\
\hline & $\mathrm{RD}$ & $24.81 b$ & $33.87 b$ & $9.60 \mathrm{~b}$ & $11.20 \mathrm{~b}$ & $33.40 \mathrm{a}$ & $48.03 b$ \\
\hline & $\mathrm{PT}$ & $24.17 \mathrm{~b}$ & $33.01 \mathrm{~b}$ & $5.33 c$ & $10.00 \mathrm{c}$ & $29.09 \mathrm{~b}$ & $46.70 \mathrm{c}$ \\
\hline & RT & $23.95 b$ & $30.42 c$ & $4.53 \mathrm{~d}$ & $7.40 \mathrm{~d}$ & $28.97 b$ & $41.10 \mathrm{~d}$ \\
\hline
\end{tabular}

PD: moldboard plowing with direct seeding, RD: rotary tiller with direct seeding, PT: moldboard plowing with mechanical transplanting, RT: rotary tiller with mechanical transplanting. Different letters within a column represent significant differences at the 5\% level of DMRT. (1H: 1st harvest, and 2H: 2nd harvest).

\section{Total NPK as affected by puddling and rice establishment approach}

Puddling and rice crop establishment approach had a significant effect on total NPK during the growing season (Table 3). Total N under PD was higher than RD, PT and RT in the growing seasons. PD recorded highest of $0.63 \mathrm{~g} \cdot \mathrm{kg}^{-1}$ resulting and increase of $26 \%$ in 2017 (for $1 \mathrm{H}$ and $2 \mathrm{H}$ respectively), and 0.59 and $0.84{\mathrm{~g} \cdot \mathrm{kg}^{-1}}^{1}$ resulting in an increase of 18 and $68 \%$ in 2018 for $1 \mathrm{H}$ and $2 \mathrm{H}$ respectively (Table 3 ). Total $\mathrm{P}$ was significantly different in both growing seasons under puddling and rice crop establishment approach, however, the highest values statistically 0.28 and $0.30 \mathrm{~g} \cdot \mathrm{kg}^{-1}$ resulting in an increase of 7.69 and $15.38 \%$ in 2017 (for $1 \mathrm{H}$ and $2 \mathrm{H}$ respectively), and 0.31 and $0.37{\mathrm{~g} \cdot \mathrm{kg}^{-1}}$ resulting in an increase of 19.23 and $42.31 \%$ in 2018 for $1 \mathrm{H}$ and $2 \mathrm{H}$ respectively were recorded under PD (Table 3). The highest 14.95 and $16.52 \mathrm{~g} \cdot \mathrm{kg}^{-1}$ resulting in a decrease of $1 \%$ and an increase of $9.40 \%$ in 2017 (for $1 \mathrm{H}$ and $2 \mathrm{H}$ respectively), and 15.42 and $16.03 \mathrm{~g} \cdot \mathrm{kg}^{-1}$ resulting in an increase of 2.12 and $6.16 \%$ in 2018 for $1 \mathrm{H}$ and $2 \mathrm{H}$ respectively were recorded under PD (Table 3).

Table 3 Total NPK condition as affected by puddling and rice establishment approach.

\begin{tabular}{|c|c|c|c|c|c|c|c|}
\hline \multirow[t]{2}{*}{$\begin{array}{l}\text { Soil } \\
\text { Depth }\end{array}$} & \multirow[t]{2}{*}{ Treatment } & \multicolumn{2}{|c|}{$\begin{array}{c}\text { Total Nitrogen } \\
\left(\mathrm{g} \cdot \mathrm{kg}^{-1}\right)\end{array}$} & \multicolumn{2}{|c|}{$\begin{array}{l}\text { Total Phosphorus } \\
\left(\mathrm{g} \cdot \mathrm{kg}^{-1}\right)\end{array}$} & \multicolumn{2}{|c|}{$\begin{array}{l}\text { Total Potassium } \\
\left(\mathrm{g} \cdot \mathrm{kg}^{-1}\right)\end{array}$} \\
\hline & & $2017(1 \mathrm{H})$ & $2017(2 \mathrm{H})$ & $2017(1 \mathrm{H})$ & $2017(2 \mathrm{H})$ & $2017(1 \mathrm{H})$ & $2017(2 \mathrm{H})$ \\
\hline \multirow{4}{*}{$0-10 \mathrm{~cm}$} & PD & $0.68 \mathrm{a}$ & $0.69 \mathrm{a}$ & $0.33 \mathrm{a}$ & $0.35 a$ & $15.94 \mathrm{a}$ & $18.02 \mathrm{a}$ \\
\hline & $\mathrm{RD}$ & $0.66 \mathrm{ab}$ & $0.67 \mathrm{a}$ & $0.31 \mathrm{~b}$ & $0.32 b$ & $15.77 b$ & $17.34 \mathrm{~b}$ \\
\hline & PT & $0.65 b$ & $0.67 \mathrm{a}$ & $0.30 \mathrm{bc}$ & $0.31 b c$ & $15.64 b c$ & $17.19 \mathrm{~b}$ \\
\hline & RT & $0.65 b$ & $0.65 b$ & $0.29 \mathrm{c}$ & $0.30 \mathrm{c}$ & $15.55 \mathrm{c}$ & $16.89 \mathrm{c}$ \\
\hline \multirow{4}{*}{$10-20 \mathrm{~cm}$} & PD & $0.64 a$ & $0.65 \mathrm{a}$ & $0.27 \mathrm{a}$ & $0.30 \mathrm{a}$ & $15.54 \mathrm{a}$ & $15.93 \mathrm{a}$ \\
\hline & RD & $0.62 b$ & $0.63 b$ & $0.26 \mathrm{a}$ & $0.28 b$ & $15.31 \mathrm{~b}$ & $15.86 \mathrm{ab}$ \\
\hline & PT & $0.62 b$ & $0.63 b$ & $0.26 a$ & $0.28 b$ & $15.29 \mathrm{~b}$ & $15.74 \mathrm{ab}$ \\
\hline & RT & $0.61 \mathrm{~b}$ & $0.61 \mathrm{~b}$ & $0.26 \mathrm{a}$ & $0.27 \mathrm{~b}$ & $15.21 \mathrm{~b}$ & $15.67 \mathrm{~b}$ \\
\hline \multirow{6}{*}{$20-30 \mathrm{~cm}$} & PD & $0.56 \mathrm{a}$ & $0.56 a$ & $0.24 a$ & $0.26 a$ & $13.38 \mathrm{a}$ & $15.61 \mathrm{a}$ \\
\hline & $\mathrm{RD}$ & $0.54 b$ & $0.56 \mathrm{a}$ & $0.23 \mathrm{ab}$ & $0.24 b$ & $13.26 \mathrm{~b}$ & $15.59 \mathrm{a}$ \\
\hline & PT & $0.53 b c$ & $0.55 b$ & $0.22 b c$ & $0.22 \mathrm{c}$ & $13.20 \mathrm{bc}$ & $15.58 \mathrm{a}$ \\
\hline & RT & $0.52 \mathrm{c}$ & $0.54 b$ & $0.21 \mathrm{c}$ & $0.22 \mathrm{c}$ & $13.12 \mathrm{c}$ & $15.55 \mathrm{a}$ \\
\hline & & \multicolumn{2}{|c|}{$\begin{array}{c}\text { Total Nitrogen } \\
\left(\mathrm{g} \cdot \mathrm{kg}^{-1}\right)\end{array}$} & \multicolumn{2}{|c|}{$\begin{array}{c}\text { Total Phosphorus } \\
\left(\mathrm{g} \cdot \mathrm{kg}^{-1}\right)\end{array}$} & \multicolumn{2}{|c|}{$\begin{array}{c}\text { Total Potassium } \\
\left(\mathrm{g} \cdot \mathrm{kg}^{-1}\right)\end{array}$} \\
\hline & & $2018(1 \mathrm{H})$ & $2018(2 \mathrm{H})$ & $2018(1 \mathrm{H})$ & $2018(2 \mathrm{H})$ & $2018(1 \mathrm{H})$ & $2018(2 \mathrm{H})$ \\
\hline \multirow{3}{*}{$0-10 \mathrm{~cm}$} & PD & $0.65 a$ & $1.14 \mathrm{a}$ & $0.33 a$ & $0.43 a$ & $16.82 \mathrm{a}$ & $16.59 \mathrm{a}$ \\
\hline & $\mathrm{RD}$ & $0.62 b$ & $1.10 \mathrm{~b}$ & $0.32 \mathrm{ab}$ & $0.38 b$ & $16.13 b$ & $14.93 b$ \\
\hline & PT & $0.62 b$ & $1.00 \mathrm{~b}$ & $0.31 b c$ & $0.36 \mathrm{c}$ & $15.86 \mathrm{c}$ & $14.91 \mathrm{~b}$ \\
\hline
\end{tabular}




\begin{tabular}{llllllll} 
& RT & $0.62 \mathrm{~b}$ & $1.03 \mathrm{~b}$ & $0.29 \mathrm{c}$ & $0.29 \mathrm{~d}$ & $15.19 \mathrm{c}$ & $14.30 \mathrm{c}$ \\
\hline \multirow{3}{*}{$10-20 \mathrm{~cm}$} & PD & $0.61 \mathrm{a}$ & $0.77 \mathrm{a}$ & $0.30 \mathrm{a}$ & $0.36 \mathrm{a}$ & $15.09 \mathrm{a}$ & $15.81 \mathrm{a}$ \\
& RD & $0.59 \mathrm{~b}$ & $0.76 \mathrm{a}$ & $0.30 \mathrm{a}$ & $0.32 \mathrm{~b}$ & $14.80 \mathrm{~b}$ & $14.75 \mathrm{~b}$ \\
& PT & $0.57 \mathrm{c}$ & $0.53 \mathrm{c}$ & $0.30 \mathrm{a}$ & $0.31 \mathrm{c}$ & $14.71 \mathrm{c}$ & $13.82 \mathrm{c}$ \\
& RT & $0.51 \mathrm{~d}$ & $0.49 \mathrm{~d}$ & $0.29 \mathrm{a}$ & $0.27 \mathrm{~d}$ & $14.46 \mathrm{~d}$ & $12.31 \mathrm{~d}$ \\
\hline \multirow{3}{*}{$20-30 \mathrm{~cm}$} & PD & $0.52 \mathrm{a}$ & $0.60 \mathrm{a}$ & $0.29 \mathrm{a}$ & $0.32 \mathrm{a}$ & $14.34 \mathrm{a}$ & $15.70 \mathrm{a}$ \\
& RD & $0.42 \mathrm{~b}$ & $0.56 \mathrm{~b}$ & $0.29 \mathrm{a}$ & $0.31 \mathrm{~b}$ & $14.21 \mathrm{~b}$ & $12.28 \mathrm{~b}$ \\
& PT & $0.41 \mathrm{c}$ & $0.53 \mathrm{c}$ & $0.25 \mathrm{~b}$ & $0.29 \mathrm{c}$ & $13.49 \mathrm{c}$ & $11.68 \mathrm{c}$ \\
& RT & $0.40 \mathrm{~d}$ & $0.49 \mathrm{~d}$ & $0.24 \mathrm{c}$ & $0.29 \mathrm{c}$ & $13.14 \mathrm{~d}$ & $10.56 \mathrm{~d}$ \\
\hline
\end{tabular}

PD: moldboard plowing with direct seeding, RD: rotary tiller with direct seeding, MT: moldboard plowing with mechanical transplanting, RT: rotary tiller with mechanical transplanting. Different letters within a column represent significant differences at the $5 \%$ level of DMRT. (1H: 1st harvest, and 2H: 2nd harvest).

Bacteria, fungi, and actinomycetes as affected by puddling and rice establishment approach Bacteria content was significantly varied among puddling and rice crop establishment approach. The highest 2.35 and $2.65\left[\times 10^{5} \mathrm{cfu}^{-1} \mathrm{~g}^{-1}\right.$ dry soil] resulting in an increase of 6.33 and $19.91 \%$ in 2017 (for $1 \mathrm{H}$ and $2 \mathrm{H}$ respectively), and 2.75 and $2.89\left[\times 10^{5} \mathrm{cfu}^{-\mathrm{g}^{-1}}\right.$ dry soil $]$ resulting in an increase of 24.43 and $30.77 \%$ in 2018 (for $1 \mathrm{H}$ and $2 \mathrm{H}$ respectively) of bacteria were observed under PD (Table 4). PD resulted in highest activity of fungi (1.60 and $1.74\left[\times 10^{3} \mathrm{cfu} \cdot \mathrm{g}^{-1} \mathrm{dry}\right.$ soil $]$ ) which markedly increased by 32.23 and $43.80 \%$ in 2017 (for $1 \mathrm{H}$ and $2 \mathrm{H}$ respectively), and 1.71 and 1.79 $\left[\times 10^{3} \mathrm{cfu} \cdot \mathrm{g}^{-1}\right.$ dry soil] resulting to an increase of 41.32 and $47.93 \%$ in 2018 for $1 \mathrm{H}$ and $2 \mathrm{H}$ respectively (Table 4). The highest 3.16 and $3.34\left[\times 10^{4} \mathrm{cfu} \cdot \mathrm{g}^{-1}\right.$ dry soil $]$ resulting in an increase of 12.86 and $19.29 \%$ in 2017 (for $1 \mathrm{H}$ and $2 \mathrm{H}$ respectively), and 3.32 and 3.30 [ $\times 10^{4} \mathrm{cfu}^{-\mathrm{g}^{-1}} \mathrm{dry}$ soil] resulting in an increase of 15.35 and $17.86 \%$ in 2018 for $1 \mathrm{H}$ and $2 \mathrm{H}$ respectively were recorded under PD (Table 4).

Table 4 Bacteria, fungi and actinomycetes condition as affected by puddling and rice establishment approach

\begin{tabular}{|c|c|c|c|c|c|c|c|}
\hline \multirow[t]{2}{*}{$\begin{array}{c}\text { Soil } \\
\text { Depth }\end{array}$} & \multirow[t]{2}{*}{ Treatment } & \multicolumn{2}{|c|}{$\begin{array}{c}\text { Bacteria } \\
\left(\times 10^{5} \mathrm{cfu} \cdot \mathrm{g}^{-1} \text { dry soil }\right)\end{array}$} & \multicolumn{2}{|c|}{$\begin{array}{c}\text { Fungi } \\
\left(\times 10^{3}{\left.\mathrm{cfu} \cdot \mathrm{g}^{-1} \text { dry soil }\right)}\right.\end{array}$} & \multicolumn{2}{|c|}{$\begin{array}{c}\text { Actinomycetes } \\
\left(\times 10^{4} \mathrm{cfu} \cdot \mathrm{g}^{-1} \text { dry soil }\right)\end{array}$} \\
\hline & & $2017(1 \mathrm{H})$ & $2017(2 \mathrm{H})$ & $2017(1 \mathrm{H})$ & $2017(2 \mathrm{H})$ & $2017(1 \mathrm{H})$ & $2017(2 \mathrm{H})$ \\
\hline \multirow{4}{*}{$0-10 \mathrm{~cm}$} & PD & $2.47 \mathrm{a}$ & $2.61 \mathrm{a}$ & $0.91 \mathrm{a}$ & $1.06 \mathrm{a}$ & $2.66 a$ & $2.86 a$ \\
\hline & $\mathrm{RD}$ & $2.31 \mathrm{~b}$ & $2.53 \mathrm{a}$ & $0.88 \mathrm{a}$ & $0.92 b$ & $2.42 b$ & $2.58 b$ \\
\hline & PT & $2.27 b$ & $2.39 b$ & $0.87 \mathrm{a}$ & $0.90 \mathrm{~b}$ & $2.26 \mathrm{bc}$ & $2.38 \mathrm{c}$ \\
\hline & RT & $1.66 \mathrm{c}$ & $1.24 \mathrm{c}$ & $0.83 \mathrm{a}$ & $0.86 \mathrm{~b}$ & $2.18 \mathrm{c}$ & $2.30 \mathrm{~d}$ \\
\hline \multirow{4}{*}{$10-20 \mathrm{~cm}$} & PD & $3.05 \mathrm{a}$ & $3.68 \mathrm{a}$ & $1.34 \mathrm{a}$ & $1.47 \mathrm{a}$ & $3.25 \mathrm{a}$ & $3.46 \mathrm{a}$ \\
\hline & $\mathrm{RD}$ & $2.98 \mathrm{ab}$ & $3.37 \mathrm{~b}$ & $1.24 \mathrm{ab}$ & $1.37 \mathrm{a}$ & $3.15 \mathrm{ab}$ & $3.33 \mathrm{ab}$ \\
\hline & PT & $2.83 b$ & $2.81 \mathrm{c}$ & $1.17 \mathrm{bc}$ & $1.28 \mathrm{a}$ & $3.11 \mathrm{ab}$ & $3.31 \mathrm{ab}$ \\
\hline & RT & $2.54 \mathrm{c}$ & $2.66 \mathrm{c}$ & $1.08 \mathrm{c}$ & $1.20 \mathrm{a}$ & $3.07 \mathrm{~b}$ & $3.24 b$ \\
\hline \multirow{6}{*}{$20-30 \mathrm{~cm}$} & PD & $1.52 \mathrm{a}$ & $1.66 \mathrm{a}$ & $2.56 \mathrm{a}$ & $2.68 \mathrm{a}$ & $3.56 \mathrm{a}$ & $3.71 \mathrm{a}$ \\
\hline & $\mathrm{RD}$ & $1.44 \mathrm{ab}$ & $1.54 \mathrm{a}$ & $2.14 b$ & $2.27 b$ & $3.31 \mathrm{~b}$ & $3.50 \mathrm{~b}$ \\
\hline & PT & $1.43 \mathrm{ab}$ & $1.35 \mathrm{~b}$ & $2.10 b$ & $2.19 b$ & $3.12 \mathrm{c}$ & $3.41 \mathrm{~b}$ \\
\hline & RT & $1.35 \mathrm{~b}$ & $1.27 \mathrm{~b}$ & $2.00 \mathrm{~b}$ & $2.16 \mathrm{~b}$ & $3.11 \mathrm{c}$ & $3.34 \mathrm{~b}$ \\
\hline & & \multicolumn{2}{|c|}{$\begin{array}{c}\text { Bacteria } \\
\left(\times 10^{5} \mathrm{cfu} \cdot \mathrm{g}^{-1} \text { dry soil }\right)\end{array}$} & \multicolumn{2}{|c|}{$\begin{array}{c}\text { Fungi } \\
\left(\times 10^{3}{\left.\mathrm{cfu} \cdot \mathrm{g}^{-1} \text { dry soil }\right)}\right.\end{array}$} & \multicolumn{2}{|c|}{$\begin{array}{c}\text { Actinomycetes } \\
\left(\times 10^{4} \mathrm{cfu} \cdot \mathrm{g}^{-1} \text { dry soil }\right)\end{array}$} \\
\hline & & $2018(1 \mathrm{H})$ & $2018(2 \mathrm{H})$ & $2018(1 \mathrm{H})$ & $2018(2 \mathrm{H})$ & $2018(1 \mathrm{H})$ & $2018(2 \mathrm{H})$ \\
\hline \multirow{4}{*}{$0-10 \mathrm{~cm}$} & PD & $2.80 \mathrm{a}$ & $2.92 \mathrm{a}$ & $1.07 \mathrm{a}$ & $1.21 \mathrm{a}$ & $2.72 \mathrm{a}$ & $2.75 a$ \\
\hline & $\mathrm{RD}$ & $2.57 \mathrm{ab}$ & $2.64 b$ & $0.95 b$ & $1.07 \mathrm{~b}$ & $2.41 b$ & $2.49 b$ \\
\hline & PT & $2.48 b$ & $2.60 \mathrm{~b}$ & $0.90 \mathrm{bc}$ & $0.96 \mathrm{bc}$ & $2.31 \mathrm{c}$ & $2.36 b c$ \\
\hline & $\mathrm{RT}$ & $1.39 \mathrm{c}$ & $1.46 \mathrm{c}$ & $0.83 c$ & $0.70 \mathrm{c}$ & $2.22 \mathrm{~d}$ & $2.30 \mathrm{c}$ \\
\hline
\end{tabular}




\begin{tabular}{llllllll}
\hline \multirow{3}{*}{$10-20 \mathrm{~cm}$} & PD & $3.74 \mathrm{a}$ & $3.89 \mathrm{a}$ & $1.41 \mathrm{a}$ & $1.47 \mathrm{a}$ & $3.33 \mathrm{a}$ & $3.43 \mathrm{a}$ \\
& RD & $3.41 \mathrm{~b}$ & $3.56 \mathrm{~b}$ & $1.30 \mathrm{~b}$ & $1.37 \mathrm{~b}$ & $3.25 \mathrm{ab}$ & $3.35 \mathrm{ab}$ \\
& PT & $2.91 \mathrm{c}$ & $3.08 \mathrm{c}$ & $1.22 \mathrm{c}$ & $1.26 \mathrm{c}$ & $3.22 \mathrm{ab}$ & $3.32 \mathrm{bc}$ \\
& RT & $2.70 \mathrm{~d}$ & $2.72 \mathrm{~d}$ & $1.11 \mathrm{~d}$ & $1.25 \mathrm{c}$ & $3.12 \mathrm{~b}$ & $3.23 \mathrm{c}$ \\
\hline \multirow{3}{*}{$20-30 \mathrm{~cm}$} & PD & $1.71 \mathrm{a}$ & $1.88 \mathrm{a}$ & $2.64 \mathrm{a}$ & $2.70 \mathrm{a}$ & $3.63 \mathrm{a}$ & $3.71 \mathrm{a}$ \\
& RD & $1.69 \mathrm{a}$ & $1.76 \mathrm{~b}$ & $2.27 \mathrm{~b}$ & $2.35 \mathrm{~b}$ & $3.41 \mathrm{~b}$ & $3.46 \mathrm{~b}$ \\
& PT & $1.40 \mathrm{~b}$ & $1.46 \mathrm{c}$ & $2.25 \mathrm{~b}$ & $2.22 \mathrm{c}$ & $3.28 \mathrm{c}$ & $3.43 \mathrm{~b}$ \\
& RT & $1.35 \mathrm{~b}$ & $1.39 \mathrm{c}$ & $2.14 \mathrm{c}$ & $2.21 \mathrm{c}$ & $3.24 \mathrm{c}$ & $3.33 \mathrm{c}$ \\
\hline
\end{tabular}

PD: moldboard plowing with direct seeding, RD: rotary tiller with direct seeding, PT: moldboard plowing with mechanical transplanting, RT: rotary tiller with mechanical transplanting. Different letters within a column represent significant differences at the $5 \%$ level of DMRT. (1H: 1st harvest, and 2H: 2nd harvest).

Catalase, phosphatase, and urease as affected by puddling and rice establishment approach Puddling and rice crop establishment approach had a significant effect catalase, phosphatase, and urease during the growing season (Table 5). Catalase under PD was higher than RD, PT and RT in the growing seasons. PD recorded highest of 1.77 and $1.72\left[0.1 \mathrm{NKMnO}_{4}\left(\mathrm{~mL} \cdot \mathrm{g}^{-1}\right)\right]$ resulting in an increase of 9.94 and $6.83 \%$ in 2017 (for $1 \mathrm{H}$ and $2 \mathrm{H}$ respectively), and 1.67 and 1.70 $\left[0.1 \mathrm{NKMnO}_{4}\left(\mathrm{~mL} \cdot \mathrm{g}^{-1}\right)\right]$ resulting in an increase of 3.73 and $5.59 \%$ in 2018 for $1 \mathrm{H}$ and $2 \mathrm{H}$ respectively (Table 5). The highest 70.43 and $66.14\left[\mathrm{P}_{2} \mathrm{O}_{5}\left(\mathrm{mg} \cdot \mathrm{kg}^{-1}\right)\right]$ resulting in an increase of $2.03 \%$ and a decrease of $4.37 \%$ in 2017 (for $1 \mathrm{H}$ and $2 \mathrm{H}$ respectively), and 76.08 and $92.90\left[\mathrm{P}_{2} \mathrm{O}_{5}\right.$ $\left.\left(\mathrm{mg} \cdot \mathrm{kg}^{-1}\right)\right]$ resulting in an increase of 10.21 and $34.58 \%$ in 2018 for $1 \mathrm{H}$ and $2 \mathrm{H}$ respectively were recorded under PD (Table 5). PD resulted in highest activity of urease (48.85 and $49.97\left[\mathrm{NH}_{4}{ }^{+} \mathrm{N}\right.$ $\left.\left(\mathrm{mg} \cdot \mathrm{kg}^{-1}\right)\right]$ ) which markedly increased by 2.84 and $5.20 \%$ in 2017 (for $1 \mathrm{H}$ and $2 \mathrm{H}$ respectively), and 49.82 and $50.38\left[\mathrm{NH}_{4}{ }^{+}-\mathrm{N}\left(\mathrm{mg} \cdot \mathrm{kg}^{-1}\right)\right]$ resulting to an increase of 4.88 and $6.06 \%$ in 2018 for $1 \mathrm{H}$ and $2 \mathrm{H}$ respectively (Table 5 ).

Table 5 Catalase, phosphatase and urease condition as affected by puddling and rice establishment approach

\begin{tabular}{|c|c|c|c|c|c|c|c|}
\hline \multirow[t]{2}{*}{$\begin{array}{c}\text { Soil } \\
\text { Depth }\end{array}$} & \multirow[t]{2}{*}{ Treatment } & \multicolumn{2}{|c|}{$\begin{array}{c}\text { Catalase } \\
{\left[0.1 \mathrm{NKMnO}_{4}\left(\mathrm{~mL} \cdot \mathrm{g}^{-1}\right)\right]}\end{array}$} & \multicolumn{2}{|c|}{$\begin{array}{c}\text { Phosphatase } \\
{\left[\mathrm{P}_{2} \mathrm{O}_{5}\left(\mathrm{mg} \cdot \mathrm{kg}^{-1}\right)\right]}\end{array}$} & \multicolumn{2}{|c|}{$\begin{array}{c}\text { Urease } \\
{\left[\mathrm{NH}_{4}^{+}-\mathrm{N}\left(\mathrm{mg} \cdot \mathrm{kg}^{-1}\right)\right]}\end{array}$} \\
\hline & & $2017(1 \mathrm{H})$ & $2017(2 \mathrm{H})$ & $2017(1 \mathrm{H})$ & $2017(2 \mathrm{H})$ & $2017(1 \mathrm{H})$ & $2017(2 \mathrm{H})$ \\
\hline \multirow{4}{*}{$0-10 \mathrm{~cm}$} & PD & $1.68 \mathrm{a}$ & $1.73 \mathrm{a}$ & $85.18 \mathrm{a}$ & $75.49 \mathrm{a}$ & $55.49 \mathrm{a}$ & $56.22 \mathrm{a}$ \\
\hline & $\mathrm{RD}$ & $1.63 \mathrm{~b}$ & $1.65 \mathrm{a}$ & $76.45 b$ & 72.33ab & $53.84 \mathrm{a}$ & $54.61 \mathrm{~b}$ \\
\hline & PT & $1.59 \mathrm{c}$ & $1.63 \mathrm{a}$ & $73.31 \mathrm{c}$ & $70.47 \mathrm{~b}$ & $53.82 \mathrm{a}$ & $54.25 \mathrm{~b}$ \\
\hline & $\mathrm{RT}$ & $1.58 \mathrm{c}$ & $1.61 \mathrm{a}$ & $70.87 \mathrm{~d}$ & $69.41 \mathrm{~b}$ & $50.28 \mathrm{~b}$ & $51.18 \mathrm{c}$ \\
\hline \multirow{4}{*}{$10-20 \mathrm{~cm}$} & PD & $1.87 \mathrm{a}$ & $1.77 \mathrm{a}$ & $69.21 \mathrm{a}$ & $67.51 \mathrm{a}$ & $46.8 \mathrm{a}$ & $48.57 \mathrm{a}$ \\
\hline & RD & $1.83 \mathrm{~b}$ & $1.74 \mathrm{a}$ & $67.02 \mathrm{ab}$ & $62.98 \mathrm{~b}$ & $44.50 \mathrm{ab}$ & $45.04 \mathrm{~b}$ \\
\hline & $\mathrm{PT}$ & $1.74 \mathrm{c}$ & $1.73 a$ & $65.29 \mathrm{~b}$ & $57.23 \mathrm{c}$ & $43.53 b$ & $44.06 \mathrm{c}$ \\
\hline & RT & $1.66 \mathrm{~d}$ & $1.69 \mathrm{a}$ & $64.40 \mathrm{~b}$ & $55.95 \mathrm{c}$ & $43.06 \mathrm{~b}$ & $43.37 \mathrm{~d}$ \\
\hline \multirow{6}{*}{$20-30 \mathrm{~cm}$} & PD & $1.77 \mathrm{a}$ & $1.65 \mathrm{a}$ & $56.89 \mathrm{a}$ & $55.42 \mathrm{a}$ & $44.26 \mathrm{a}$ & $45.13 \mathrm{a}$ \\
\hline & $\mathrm{RD}$ & $1.74 \mathrm{ab}$ & $1.65 \mathrm{a}$ & $54.44 \mathrm{ab}$ & $52.64 \mathrm{~b}$ & $43.53 \mathrm{a}$ & $43.57 \mathrm{~b}$ \\
\hline & PT & $1.69 \mathrm{bc}$ & $1.64 \mathrm{a}$ & $53.35 \mathrm{bc}$ & $52.30 \mathrm{~b}$ & $42.95 \mathrm{a}$ & $43.56 \mathrm{~b}$ \\
\hline & $\mathrm{RT}$ & $1.67 \mathrm{c}$ & $1.53 \mathrm{a}$ & $51.47 \mathrm{c}$ & $51.16 \mathrm{~b}$ & $41.72 \mathrm{a}$ & $42.27 \mathrm{c}$ \\
\hline & & \multicolumn{2}{|c|}{$\begin{array}{c}\text { Catalase } \\
{\left[0.1 \mathrm{NKMnO}_{4}\left(\mathrm{~mL} \cdot \mathrm{g}^{-1}\right)\right]}\end{array}$} & \multicolumn{2}{|c|}{$\begin{array}{c}\text { Phosphatase } \\
{\left[\mathrm{P}_{2} \mathrm{O}_{5}\left(\mathrm{mg} \cdot \mathrm{kg}^{-1}\right)\right]}\end{array}$} & \multicolumn{2}{|c|}{$\begin{array}{c}\text { Urease } \\
{\left[\mathrm{NH}_{4}^{+}-\mathrm{N}\left(\mathrm{mg} \cdot \mathrm{kg}^{-1}\right)\right]}\end{array}$} \\
\hline & & $2018(1 \mathrm{H})$ & $2018(2 \mathrm{H})$ & $2018(1 \mathrm{H})$ & $2018(2 \mathrm{H})$ & $2018(1 \mathrm{H})$ & $2018(2 \mathrm{H})$ \\
\hline \multirow{4}{*}{$0-10 \mathrm{~cm}$} & PD & $1.74 \mathrm{a}$ & $1.78 \mathrm{a}$ & $91.68 \mathrm{a}$ & $114.74 \mathrm{a}$ & $56.28 \mathrm{a}$ & $57.04 \mathrm{a}$ \\
\hline & $\mathrm{RD}$ & $1.52 \mathrm{~b}$ & $1.46 \mathrm{~b}$ & $89.37 \mathrm{a}$ & $111.88 \mathrm{ab}$ & $55.06 \mathrm{~b}$ & $56.15 b$ \\
\hline & PT & $1.14 \mathrm{c}$ & $1.29 \mathrm{c}$ & $85.21 \mathrm{a}$ & $110.64 b$ & $54.01 \mathrm{c}$ & $55.02 \mathrm{c}$ \\
\hline & RT & $1.09 \mathrm{~d}$ & $1.28 \mathrm{c}$ & $84.49 \mathrm{a}$ & $103.42 \mathrm{c}$ & $52.63 \mathrm{~d}$ & $53.44 d$ \\
\hline
\end{tabular}




\begin{tabular}{llllllll}
\hline \multirow{2}{*}{$10-20 \mathrm{~cm}$} & PD & $1.88 \mathrm{a}$ & $2.02 \mathrm{a}$ & $79.66 \mathrm{a}$ & $89.93 \mathrm{a}$ & $48.21 \mathrm{a}$ & $48.88 \mathrm{a}$ \\
& RD & $1.73 \mathrm{~b}$ & $1.95 \mathrm{a}$ & $74.98 \mathrm{~b}$ & $83.32 \mathrm{~b}$ & $47.17 \mathrm{~b}$ & $48.24 \mathrm{a}$ \\
& PT & $1.42 \mathrm{c}$ & $1.91 \mathrm{a}$ & $68.47 \mathrm{c}$ & $80.68 \mathrm{bc}$ & $46.34 \mathrm{c}$ & $47.25 \mathrm{~b}$ \\
& RT & $1.22 \mathrm{~d}$ & $1.74 \mathrm{~b}$ & $65.77 \mathrm{c}$ & $79.14 \mathrm{c}$ & $45.40 \mathrm{~d}$ & $46.06 \mathrm{c}$ \\
\hline \multirow{3}{*}{$20-30 \mathrm{~cm}$} & PD & $1.38 \mathrm{a}$ & $1.31 \mathrm{a}$ & $56.91 \mathrm{a}$ & $74.02 \mathrm{a}$ & $44.98 \mathrm{a}$ & $45.21 \mathrm{a}$ \\
& RD & $1.15 \mathrm{~b}$ & $1.15 \mathrm{~b}$ & $53.60 \mathrm{ab}$ & $69.27 \mathrm{~b}$ & $44.28 \mathrm{~b}$ & $45.02 \mathrm{a}$ \\
& PT & $1.02 \mathrm{c}$ & $0.95 \mathrm{c}$ & $52.41 \mathrm{ab}$ & $66.94 \mathrm{~b}$ & $43.61 \mathrm{c}$ & $44.14 \mathrm{~b}$ \\
& RT & $0.91 \mathrm{~d}$ & $0.91 \mathrm{c}$ & $50.50 \mathrm{~b}$ & $61.01 \mathrm{c}$ & $43.40 \mathrm{c}$ & $44.10 \mathrm{~b}$ \\
\hline
\end{tabular}

PD: moldboard plowing with direct seeding, RD: rotary tiller with direct seeding, PT: moldboard plowing with mechanical transplanting, RT: rotary tiller with mechanical transplanting. Different letters within a column represent significant differences at the $5 \%$ level of DMRT. (1H: 1st harvest, and 2H: 2nd harvest).

\section{Grain yield analysis}

Puddling and rice establishment approach had a significant effect on rice grain yield (Fig. 4). PD recorded the highest increase in both years and harvesting times, whilst RT recorded the lowest. PD recorded an increase of 32.38 and $14.33 \%$ in 2017 , and 33.28 and $13.22 \%$ in 2018 respectively for $1 \mathrm{H}$ and $2 \mathrm{H}$ than under $\mathrm{RT}$.

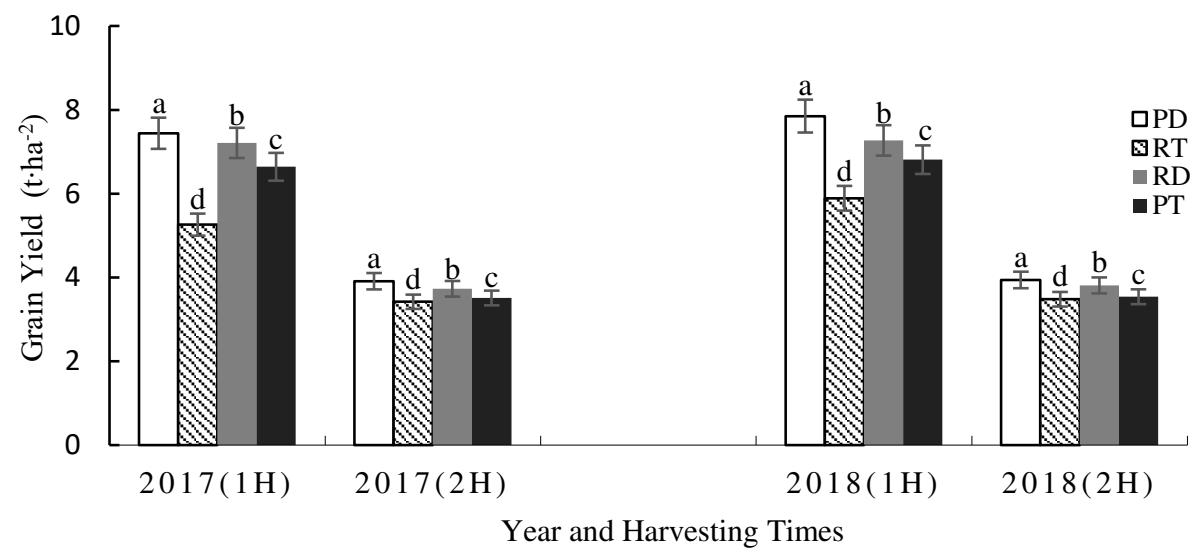

Figure 4. Puddling, direct seeding and mechanical transplanting on ratoon rice yield. PD: moldboard plowing with direct seeding, RD: rotary tiller with direct seeding, PT: moldboard plowing with mechanical transplanting, RT: rotary tiller with mechanical transplanting. Different letters within a column represent significant differences at the 5\% level of DMRT. (1H: 1st harvest, and 2H: 2nd harvest).

\section{Discussion}

Environment issues and human activities can cause alteration in the soil physical properties (i.e., bulk density), which can be detrimental to crop output ${ }^{17}$. A significant reduction in soil bulk density was observed under PD. This resulted from the total overturn of the soil resulting from the plow. This process influences the soil aggregates steadiness, leading to soil deformation structure. There was also high incorporation of straw residue which resulted in buildup of adequate carbonbased matter in the soil medium, as the high buildup of carbon-based matter results in enhancement in soil aggregates ensuing in a reduction in soil bulk density. This result is consistent with a previous study in which moldboard plowing reduces soil bulk density when combined with direct seeding ${ }^{6}$.

The results showed that PD has a tendency to improve soil $\mathrm{pH}$ compared to the order combination. The improved $\mathrm{pH}$ under PD was as a result of reduced water movement, which encouraged the retention of nutrients and hydrogen ions from the crop residue and the mineralization of inorganic materials. The slow response to crop and puddling and variable nature 
of SOC measurements requires a significant time before the direction of change can be assessed ${ }^{18}$. Generally, intensive puddling can lead to decline in SOC destroying soil structure, exposing soil aggregates and aggravating soil carbon-based matter putrefaction ${ }^{19}$. However, PD improved the SOC due to the high incorporation of rice straw into the soil as a result of reduction in soil disturbance and reduced conversion rate of soil carbon-based matter leading higher SOC by moldboard plow, this confirms study done ${ }^{19}$. Available and total NPK improved under PD, due to decomposition of carbon-based matter and conversion of nutrient induced by the crop residue and associated actions of beneficial microorganisms. Also, less loss in $\mathrm{N}$ through immobilization, volatilization, denitrification, and leaching ${ }^{20}$, high SOC incorporation by crop residue as moldboard plowing could be more effective in increasing soil fertility in deeper soils caused an improvement in $\mathrm{K}$ and $\mathrm{P}$ as it was due to the redistribution of $\mathrm{P}$ and $\mathrm{K}$ at lower soil layers and also the contact between $\mathrm{K}$ and $\mathrm{P}$ and soil particles ${ }^{21-23}$.

Soil enzymes play a critical role in nutrient cycling of the soil, which results from tillage practices ${ }^{24}$. Puddling and rice cultivation modes had a considerable effect on the soil biological properties. PD observed high bacteria resulting from the high build-up and amalgamation of the rice crop residue ${ }^{25,6}$, also the available substrates which in turn influenced the soil bacteria profusion by the effect of the implement type ${ }^{6}$. However, less buildup of rice stover on the soil by $\mathrm{RD}$ and RT treatment, and the high compaction of the soil may have led in the decreased in bacterial population.

Soil fungi were improved under PD resulting from the putrefaction of carbon-based matter resulting from the high integration of rice stover and the augmented soil water. Also, less plow uproar of the soil lead to an improvement in the soil fungi. RD and RT lead to high compaction of the soil resulting from rice transplanting leading to disturbing effect on fungi abundance ${ }^{6}$. PD improved soil actinomycetes which may be a resultant of sufficient buildup of rice stover in the soil, as high carbon-based matter soils lead to improvement in actinomycetes population. Reduced soil uproar during direct seeding under PD improved catalase by enhancing the substrates, which is in agreement with work done by Jin et al. ${ }^{26}$ who observed higher catalase activity in shallow tilling practices. PD treatment improved soil urease and phosphatase likened to the other treatments, this result is in support of findings from $^{6}$, who observed increase in urease and phosphatase population under moldboard plowing combined with direct seeding. This increase may result from the high integration of rice stover, resulting to a more putrefaction of soil carbonbased

matter.

PD showed an increase in grain yield compared to the other treatments higher yield under PD resulted from good crop condition enhanced soil bulk density for root proliferation aiding to more accessibility of plant nutrients and soil moisture this result supports work done by ${ }^{27,30}$ who observed higher grain yield under direct-seeding rice as likened with flooded rice transplanting higher grain yield has also been recorded under direct seeding compared to that of transplanted rice $^{31-34,6}$.

\section{Conclusions}

On the basis of current study, it may be concluded that among all the treatments, moldboard plowing combined with direct seeding improved the soil bulk density, chemical properties (SOC, $\mathrm{pH}$, total NPK and available NPK), and biological properties (bacteria, fungi, actinomycetes, urease, catalase, and phosphatase) resulting in higher rice grain yield by 32.38 and $14.33 \%$ in 2017 , and 33.28 and $13.22 \%$ in 2018 respectively for $1 \mathrm{H}$ and $2 \mathrm{H}(1 \mathrm{H}$ : 1 st harvest, and $2 \mathrm{H}$ : 2nd harvest) compared with the other treatments. Therefore, PD should be accepted as a suitable combined 
management practices to obtaining good soil productivity and achieving sustainable rice yield under the prevailing climatic conditions.

\section{Author Contributions}

Conceptualization; Project administration and supervision: (Li Jiuhao), Formal analysis and investigation; Writing -original draft preparation: (Evans Asenso), Data processing: (Zhimin Wang), Writing - review and editing; Project administration and supervision; Submission: (Lian $\mathrm{Hu})$. All authors read and approved the final manuscript.

\section{Funding}

The research leading to these results received funding from the National Key Research and Development Program of China under Grant Agreement No. 2016YFD0700301, and the National Natural Science Foundation of China under Grant Agreement No. 31601225.

\section{Conflicts of interest}

The authors declare no conflict of interest.

\section{Data availability}

The data used to support the findings of this study are available from the corresponding author upon request.

\section{Statement of Permission or License to Use Rice Variety (Meixiangzhan-2)}

We confirmed that the collection of the plant material in this study complies with relevant institutional, national, and international guidelines and legislation. The seeds of Meixiangzhan-2 in present study were provided by College of Agriculture, South China Agricultural University, and we have permission to the seeds. Meixiangzhan-2 (Lemont $\times$ Fengaozhan) was bred by Rice Research Institute, Guangdong Academy of Agricultural Sciences and is widely cultivated in South China. More information of this cultivar could be found in https://www.ricedata.cn/.

\section{References}

1. Food and Agricultural Organization. Word Population Review: Rice Production by Country 2021. https://worldpopulationreview.com/country-rankings/rice-production-by-country; http://www.fao.org/faostat/en/\#data/QC Assessed on August 12, 2021. (2021)

2. Kirchhof, G., Priyono, S., Utomo, W. H., Adisarwanto, T., Dacanay, E. V. \& So, H. B. The effect of soil puddling on soil physical properties and the growth of rice and post-rice crops. Soil Tillage Res. 56, 37-50 (2000).

3. Zhang, Z. B., Zhou, H., Lin, H. \& Peng, X. Puddling intensity, sesquioxides, and soil organic carbon impacts on crack patterns of two paddy soils. Geoderma 262, 155-164 (2016).

4. Nunes, M. R., van Es, H. M., Schindelbeck, R. R., Ristow, A. J. \& Ryan, M. No-till and cropping system diversification improve soil health and crop yield. Geoderma 328, 30-43 (2018).

5. Chauhan, B. S. Weed ecology and weed management strategies for dry-seeded rice in Asia. Weed Technol. 26, 1-13 (2012).

6. Asenso, E., Zhang, L., Tang, L., Issaka, F., Tian, K., Li, J. \& Hu, L. Moldboard plowing with direct seeding improves soil properties and sustainable productivity in ratoon rice farmland in Southern China. Sustainability 11, 1-12 (2019). 
7. Pandey, S. \& Velasco, L. Trends in crop establishment methods in Asia and research issues Rice is Life: Scientific Perspectives for the 21st Century, Proceedings of the World Rice Research Conference, 4-7 November 2004, Tsukuba, Japan.178-181, (2005).

8. Farooq, M., Siddique, K. H. M., Rehman, H., Aziz, T., Lee D-J. \& Wahid, A. Rice direct seeding: Experiences, challenges and opportunities. Soil Tillage Res. 111, 87-98 (2011).

9. Gong, Z. T., Zhang, G. L. \& Chen, Z. C. Pedogenesis and Soil Taxonomy. Science Press, Beijing, China. (In Chinese, 2007).

10. Hu, L., Du, P., Luo, H. W., Cheng, S. R., Wu, T. Y., He, J., Liu, Y. F., Meng, S. B., Chen, B. Y., Wang, Z. M. \& Tang, X. R. The effect of different cultivation methods on rice growth and development. Appl. Ecol. Env. Res. 17, 3867-3875 (2019).

11. Arshad, M. A., Franzluebbers, A. J. \& Azooz, R. H. Components of surface soil structure under conventional and no-tillage in northwestern Canada. Soil Tillage Res. 53, 41-47 (1999).

12. Ferraro, D. O. \& Ghersa, C. M. Quantifying the crop management influences on arable soil condition in the Inland Pampa (Argentina). Geoderma 141, 43-52 (2007).

13. Bates, R. G. Electrometric pH determination, theory and practice. Wiley, New York, (1954).

14. Black, C. A. Methods of Soil Analysis. Ameri Soc Agron, Madison, WI, (1973).

15. Bao, S. D. Soil and Agricultural Chemistry Analysis. Chinese Agricultural Publishing House, Beijing, (2005).

16. Bray, R. H. \& Kurtz, L. T. Determination of total, organic, and available forms of phosphorus in soils. Soil Sci. 59, 39-45 (1945).

17. Batey, T. \& McKenzie, D. C. Soil compaction: Identification directly in the field. Soil Use Manag. 22, 123-131(2006).

18. Lal, R. Is crop residue a waste? J. Soil Water Conserv. 59, 136a-139a (2004a).

19. Xue, J. F., Pu, C., Liu, S. L., Chen, Z. D., Chen, F., Xiao, X. P., Lal, R. \& Zhang, H. L. Effects of tillage systems on soil organic carbon and total nitrogen in a double paddy cropping system in Southern China. Soil Tillage Res. 153, 161-168 (2015).

20. Malhi, S. S., Grant, C. A., Johnston, A. M. \& Gill, K. S. Nitrogen fertilization management for no-till cereal production in the Canadian Great Plains: a review. Soil Tillage Res. 60,101122 (2001).

21. Zibilske, L. M., Bradford, J. M., Smart, J. R. Conservation tillage induced changes in organic carbon, total nitrogen and available phosphorus in a semi-arid alkaline subtropical soil. Soil Tillage Res. 66,153-163 (2002).

22. Redel, Y. D., Rubio, R., Rouanet, J. L. \& Borie, F. Phosphorus bioavailability affected by tillage and crop rotation on a Chilean volcanic derived Ultisol. Geoderma 139, 388-396 (2007).

23. Rheinheimer, D. D. \& Anghinoni, I. Accumulation of soil organic phosphorus by soil tillage and cropping systems under subtropical conditions. Commun. of Soil Sci. and Plant Analy. 34, 2339-2354 (2003).

24. Blagodatskaya, E. \& Kuzyakov, Y. Mechanisms of real and apparent priming effects and their dependence on soil microbial biomass and community structure: Critical review. Biol. Fert. Soils 45,115-131(2008).

25. Mathew, R. P., Feng, Y., Githinji, L., Ankumah, R. \& Balkcom, K. S. Impact of No-Tillage and Conventional Tillage Systems on Soil Microbial Communities. Applied Environ. Soil Sci. 548620 (2012). 
26. Jin, K., Sleutel, S., Buchan, D., De Neve, S., Cai, D. X., Gabriels, D. \& Jin, J. Y. Changes of soil enzyme activities under different tillage practices in the Chinese Loess Plateau. Soil Tillage Res. 104, 115-120 (2009).

27. Gupta, R. K., Naresh, R. K., Hobbs, P. R., Jiaguo, Z. \& Ladha, J. K. Sustainability of PostGreen Revolution Agri-culture. The Rice-Wheat Cropping Systems of the Indo-Gangetic Plains and China. In Improving the Productivity and Sustainability of Rice-Wheat Systems: Issues and Impacts; ASA Special Publication: Washington, DC, USA, Volume 65,1-25 (2003).

28. San-oh, Y., Mano, Y., Ookawa, T., Hirasawa, T. Comparison of dry matter production and associated characteristics between direct-sown and transplanted rice plants in a submerged paddy field and relationships to planting pattern. Field Crops Res. 87, 43-58 (2004).

29. Tabbal, D. F., Bouman, B. A. M., Bhuiyan, S. I., Sibayan, E. B. \& Sattar, M. A. On-farm strategies for reducing water input in irrigated rice: Case studies in the Philippines. Agric. Water Manag. 56, 93-112 (2002).

30. Ali, M. A., Ladha, J. K., Rickman, J. \& Lales, J. S. Comparison of different methods of rice establishment and nitrogen management strategies for lowland rice. J. Crop Improve. 16, 173189 (2006).

31. Bhushan, L., Ladha, J. K., Gupta, R. K., Singh, S., Tirol-Padre, A., Saharawat, Y. S., Gathala, M. \& Pathak, H. Saving of water and labor in a rice-wheat system with no-tillage and direct seeding technologies. Agron. J. 99, 1288-1296 (2007).

32. Singh, G. \& Singh, O. P. Effect of method of seeding and level of nitrogen on yield and yield attributes of rice under flood-affected conditions. Ind. J. Agron. 38, 551-554 (1993).

33. Yoshinaga, S., Wakimoto, K., Tasaka, K., Matsushima, K., Togashi, T. \& Shimotsubo, K. Growth characteristics of submerged hill-seeded rice (Oryza sativa L.) in warmer regions of Japan: Differences of growth as compared with broadcast-seeded rice. Japan J. Crop Sci. 70, 541-547 (2001).

34. Hayashi, S., Kamoshita, A., Yamagishi, J., Kotchasatit, A. \& Jongdee, B. Genotypic differences in grain yield of transplanted and direct-seeded rainfed lowland rice (Oryza sativa L.) in northeastern Thailand. Field Crops Res. 102, 9-21 (2007). 